logos_i_ethos_2016_(40)_numer_specjalny_1, s.63-75

DOI: http://dx.doi.org/10.15633/lie.1699

Katarzyna Cikała-Kaszowska

Uniwersytet Papieski Jana Pawła II w Krakowie

\title{
Ponowoczesna koncepcja szczęścia
}

Pytania o to, czym jest szczęście i jak je osiągnąć, od dawien dawna trapiły ludzkość. Z czasem pojawiały się różne teorie dotyczące eudajmonii i możliwości jej osiągnięcia, autorstwa filozofów, teologów i socjologów. Wariantów było wiele, a ich adekwatność była zależna od panujących sytuacji społeczno-ekonomicznych, rozwoju społecznego, religii i zmian kulturowych. Wraz $\mathrm{z}$ rozwojem techniki człowiek skupił się na wartości odkryć naukowych, nowościach technologicznych, często spychając problemy etyczne na margines. Jednak pomimo stechnicyzowania społeczeństwa i kierowania się w stronę wartości rynkowych, jednostka wciąż odczuwała pragnienie poznania, czym jest szczęście. Dziś można mówić o tym, że współczesny człowiek żyje w społeczeństwie konsumpcyjnym, ponowoczesnym i skupia się na wartościach ekonomicznych. W gąszczu informacji wciąż poszukuje szczęścia i chce być szczęśliwy. Jednocześnie tak określana jednostka charakteryzuje nowy typ człowieka i nową definicję szczęścia opisywaną np. przez Zygmunta Baumana.
Katarzyna Cikała-Kaszowska, magister filozofii (spec. etyka stosowana), doktorantka przy Katedrze Etyki Wydziału Filozoficznego Uniwersytetu Papieskiego Jana Pawła II w Krakowie, absolwentka Dziennikarstwa i Komunikacji Społecznej na tej samej uczelni. Inicjatorka konferencji naukowych, członek zarządu Samorządu Doktorantów UPJPII oraz w latach 2013/2014 pełnomocnik ds. uniwersytetów przy Krajowej Reprezentacji Doktorantów. Zainteresowania naukowe: etyka, filozofia społeczna, filozofia konsumpcjonizmu, postmodernizm, komunikacja społeczna. Wybrane publikacje: Chciwość w spoleczeństwie konsumpcyjnym, czyli o potrzebach konsumenta, [w:] Chciwość w życiu publicznym, red. W. Zuziak, J. Mysona Byrska, Kraków 2013; Społeczeństwo konsumentów. Kilka słów o racjonalizacji na sprzedaz, [w:] Społeczeństwo rozumne? O relacji między jednostkami a racjonalnością, red. K. Cikała, K. Drążkiewicz, W. B. Zieliński, Kraków 2014; Normy w społeczeństwie nadzoru, [w:] Normy, dewiacje i kontrola społeczna, t. 15, red. J. Zamecka, Warszawa 2014. 
Celem niniejszego artykułu jest przyjrzenie się ponowoczesnej koncepcji szczęścia i jej aspektom na podstawie prac Zygmunta Baumana. W trakcie analiz zostaną przywołane również teorie innych myślicieli zajmujących się szczęściem. Przygotowane zestawienie ma jeszcze lepiej zobrazować ponowoczesne podejście do kwestii szczęścia i szczęśliwego życia. Tym samym nakreślone zostaną różnice pomiędzy starszymi koncepcjami eudajmonii a tym bardziej współczesnym, skupiającymi się na kwestiach społeczeństwa konsumpcyjnego.

\section{Różne ujęcia szczęścia}

Dotychczas filozofowie pojmowali szczęście jako: dobre poczucie, sprzyjający los, pomyślność, przyjemność czy też działanie bogów. W zależności od szkoły, z jakiej się wywodzili, ich fundament filozoficzny był odmienny. Według Sokratesa poczucie szczęścia związane jest z mądrością, należy więc posiadać wiedzę o tym, co jest dobre, a co złe ${ }^{1}$. Ten intelektualizm etyczny i ciągła troska o własną duszę mają pomóc w odnalezieniu szczęścia. Seneka, przedstawiciel filozofii stoickiej, w swoich pismach stwierdzał na przykład, że „nieszczęśliwy jest ten, kto czyni coś wbrew swej woli”2. W swoim dziele Myśli pisał również o roli spokoju, uczciwości, umiarkowania w doznawaniu szczęścia. Platon twierdził, że osiągnięcie najwyższego dobra, czyli harmonijny rozwój osobowości i pielęgnowanie duszy, gwarantuje prawdziwe szczęście ${ }^{3}$. Z kolei Arystoteles odróżniał od szczęścia pomyślność i przyjemność. Szczęście było dla niego związane z cnotą, czyli z dążeniem do czynienia dobra. „Szczęście jest pewnego rodzaju działaniem duszy, zgodnym z nakazami doskonałej dzielności”“4 - pisał. Filozofowie scholastyczni powiedzą później, że szczęście to dobra religijne, gdyż tylko one są trwałe. Ponad subiektywne

\footnotetext{
1 Zob. Platon, Protagoras, http://katedra.uksw.edu.pl/biblioteka/platon_protagoras.pdf (9.06.2015).

Seneka, Myśli, tłum. S. Stabryła, Kraków 1989, s. 452.

Zob. F. Copleston, Historia filozofii, t. 1, tłum. H. Bednarek, Warszawa 2004, s. 197.

4 Arystoteles, Etyka nikomachejska, tłum. D. Gromska, ks. I, http://sady.up.krakow.pl/ antfil.arystoteles.etykanikom.htm (9.06.2015).
} 
odczucia będą stawiali rolę łaski i Boga w dążeniu do szczęścia. Jak pisze św. Tomasz z Akwinu: „Szczęśliwość to osiągnięcie doskonałego dobra. Ktokolwiek więc jest zdolny do doskonałego dobra, ten może dojść do szczęśliwości [...] Doskonała zaś szczęśliwość człowieka polega na oglądaniu istoty Bożej”s. W nowożytności będzie można zauważyć teorie uznające, że szczęście to coś subiektywnego - zatem, by je osiągnąć, należy spełnić własne pragnienia, kierować się w stronę własnych potrzeb.

Jedną z bardziej rozpowszechnionych analiz dotyczących szczęścia jest działo Władysława Tatarkiewicza O szczęściu, opublikowane podczas II wojny światowej. W tych trudnych i nieszczęśliwych czasach dokonał on analizy szczęścia i jego różnych odmian. Filozof zaznaczył, że istnieje różnica pomiędzy pomyślnością a szczęściem. Jednak w myśleniu potocznym pojęcia te bywają ze sobą utożsamiane. Gdy mówimy, że jesteśmy szczęśliwi, często mamy na myśli poczucie, iż los nam sprzyja, coś idzie zgodnie z planem. Tymczasem Tatarkiewicz definiuje pomyślność jako dobry $\operatorname{los}^{6}$, który już w starożytności był utożsamiany z opieką bogów. Z kolei szczęście to dla Tatarkiewicza "zadowolenie z całości życia”" Filozof wiele razy podkreśla, że ocenić, czy jesteśmy szczęśliwi, możemy dopiero z pewnej perspektywy, na przykład pod koniec życia. Poczucie szczęścia nie jest czymś chwilowym i natychmiastowym, jest to zjawisko złożone i trwałe. Szczęśliwym jest ten, kto się zbliża do ideału. Ponadto - co ważne - szczęśliwe życie to wcale nie takie, które pozbawione jest udręk i niepowodzeń. Szczęśliwy człowiek to właśnie ten, który potrafi zdystansować się od doznawanych krzywd i docenia chwilowe przyjemności ${ }^{8}$. Jak pisze filozof: „w życiu nie może brakować tego, co należy do szczęśliwego życia, nawet cierpienia”; „,szczęśliwy jest naprawdę ten, kto swego szczęścia nie zawdzięcza szczęściu” ${ }^{10}$. Tatarkiewicz w swoich

5 Św. Tomasz z Akwinu, O szczęściu, [w:] Cel ostateczny czyli szczęście, tłum. F. W. Bednarski, zag. 5, http://www.katedra.uksw.edu.pl/suma/suma_indeks.htm (9.06.2015).

Zob. W. Tatarkiewicz, O szczęściu, Warszawa 1979, s. 50.

W. Tatarkiewicz, O szczęściu, dz. cyt., s. 31.

Zob. W. Tatarkiewicz, O szczęściu, dz. cyt., s. 32.

W. Tatarkiewicz, O szczęściu, dz. cyt., s. 25.

10 W. Tatarkiewicz, O szczęściu, dz.cyt. 
analizach pisze o różnych rodzajach szczęścia. Wymienia m.in. szczęście jako moment trwały, szczęście przedmiotowe, szczęście jako spokój i beztroska. Wielość ujęć szczęścia ma uświadomić czytelnikowi, że każde z nich jest tylko pewnym rozumieniem szczęścia, zaś całościowy ogląd daje dopiero tzw. głębsze poczucie szczęścia.

Analizujący fenomen szczęścia socjolodzy mogą umieścić je w perspektywie społecznej, tym samym zastanawiając się nad szczęściem grup społecznych, satysfakcją z relacji interpersonalnych. Skupią się także na analizie dążeń jednostek, priorytetów życiowych, kwestiach spełnienia zawodowego. Z kolei teologowie w swych rozważaniach będą opisywali szczęście jako efekt właściwej relacji z Bogiem, życia zgodnego z wartościami chrześcijańskimi, obietnicę raju po śmierci. Każda z dziedzin humanistycznych będzie przyglądać się szczęściu ze swej perspektywy, próbując znaleźć przepis na szczęśliwe życie.

U progu XXI wieku do podobnych dążeń zaczęli zmierzać myśliciele zajmujący się filozofią postmodernizmu, ponowoczesnością czy też socjologią codzienności. By jednak przyjrzeć się definicji szczęścia proponowanej przez ten nurt intelektualny, musieli najpierw przeanalizować współczesne trendy, pomysły na życie, wartości, które pojawiają się w przestrzeni społecznej. Przyjęli przy tym określoną wizję człowieka człowieka konsumenta czy też człowieka ponowoczesnego.

\section{Oblicza eudajmonii}

Już starożytni myśliciele, zastanawiając się nad sensem życia, przywoływali termin „eudajmonia”. Dla Platona i Sokratesa oznaczał on poczucie doskonałości życia, które człowiek mógł zweryfikować dopiero na koniec ziemskiej egzystencji ${ }^{11}$. Dla Arystotelesa eudajmonia oznaczała harmonię, w sensie dążenia do złotego środka. Osiągał eudajmonię ten, kto nie używał nadto uciech cielesnych, ale także nie odmawiał ich sobie, gdy były konieczne. Co więcej, w swoim postępowaniu dążył do wartości pośrednich, a nie skrajnych - nie był chytry, ale też nie trwonił pieniędzy. 
Kluczowa była tu cnota umiarkowania. Umiarkowanie ćwiczyło bowiem nie tylko ciało, ale przede wszystkim wnętrze człowieka - uczyło wytrwałości, a to wyrabiało kolejne cnoty ${ }^{12}$.

$\mathrm{Na}$ tle przywołanych myślicieli zostaje przywołana teoria ponowoczesna, która również przedstawia swego rodzaju eudajmonię - koncepcję szczęścia. Ponowoczesna eudajmonia będzie marzeniem każdego konsumenta, człowieka ciągle pragnącego być doskonalszym i posiadającym więcej. Podobne przekonanie $\mathrm{w}$ swoich pracach przedstawia Zygmunt Bauman. Autor podkreśla, że współczesnemu człowiekowi niejako wmówiono, że gdy tylko będzie więcej konsumował, stanie się szczęśliwszy ${ }^{13}$. Efekt tego rozumowania jest zupełnie odwrotny. Ludzie, którzy są zaprogramowani na ciągłe pokonywanie własnych wyników, porównywanie, dążenie do społecznie postrzeganych symboli dostatku, bardzo często doprowadzają się do depresji, lęków i prób samobójczych. Bauman, kontynuując wywód, stwierdza, że ciągłe dążenie ludzi do posiadania coraz lepszych dóbr w gruncie rzeczy prowadzi do nieszczęścia jednostki. Gdy kupujemy coraz więcej samochodów, wrastają szanse na wypadki i katastrofy; gdy przeprowadzamy się do coraz lepszych i nowocześniejszych mieszkań, pogłębiamy różnice społeczne i tym bardziej możemy spodziewać się „wizyty” złodziei. Jak pisze autor: „We wszystkich tych sytuacjach i w niezliczonej liczbie przypadków pieniądze zmieniają właścicieli, co przyczynia się do poprawy wskaźników PKB. To pewne. Znacznie mniej oczywisty wydaje się równoczesny wzrost poczucia szczęścia wśród osób przyjmujących środki antydepresyjne, ofiar wypadków samochodowych, podróżnych taszczących butelki z wodą oraz tych wszystkich, którzy lękają się o przyszłość, drżąc z obawy o własne bezpieczeństwo" ${ }^{14}$.

Wzrost zamożności ludzi z jednej strony poprawia stan gospodarki kraju, jednak z drugiej negatywnie wpływa na jednostkę i jej otoczenie. Nie chodzi tu o dezaprobatę w stosunku do nowych rzeczy, a o dążenie

12 Zob. F. Copleston, Historia filozofii, dz. cyt., s. 301-317.

13 Zob. Z. Bauman, Sztuka życia, tłum. T. Kunz, Kraków 2009, s. 11.

14 Z. Bauman, Sztuka życia, dz. cyt., s. 12. 
do posiadania dóbr, które w gruncie rzeczy nie są potrzebne, ale warto je mieć $\mathrm{z}$ uwagi na to, by być modnym. W społeczeństwie ponowoczesnym chodzi o zauważenie, dostrzeżenie człowieka w tłumie ludzi, którzy wyglądają podobnie. Kreowany przez media wizerunek człowieka wciąż czeka na udoskonalenie, co z kolei obiecuje poprawę samopoczucia, posiadania większej grupy przyjaciół, społecznego szacunku. Konsumowanie ma być natychmiastowe, tak by wyprodukowane dobra nie musiały zbyt długo zalegać na sklepowych półkach. „Konsumować to tyle, co inwestować we własne członkostwo w społeczeństwie, które w społeczeństwie konsumentów przekłada się na pokupność: na nabycie przedmiotów, na które istnieje już popyt rynkowy, albo stworzenie popytu na przedmioty już posiadane"15 - pisze Bauman.

Od konsumpcji nie da się uciec, a kupowanie dóbr to inwestowanie we własne członkostwo w społeczeństwie. Bauman pisze o sprowadzeniu człowieka do wartości towaru ${ }^{16}$. Takie uprzedmiotowienie ma na celu możliwość szybkiej manipulacji człowiekiem. Tym samym człowiek, stając się towarem konsumpcyjnym, nie powinien myśleć już o takich kwestiach jak szczęście, miłość czy odpowiedzialność. To, o czym powinien myśleć, jest z góry ustanowione przez bloki reklamowe i sławnych ludzi promujących odpowiednie wzorce życiowe. Stąd też przedstawiony tam jest odpowiedni obraz szczęścia. Szczęście ma pojawiać się po zakupie dóbr, podniesieniu jakości życia, ulepszeniu ciała, pojawieniu się w odpowiednich kręgach - tak postrzega te kwestie przeciętny konsument. Szczęście jest następstwem wyboru, decyzji, jest obietnicą składaną przez reklamy i zaufanych ludzi. Stąd też można powiedzieć, że szczęście jest niespełnioną obietnicą. Dzieje się tak, gdyż kolejne dobra rozczarowują. Konsument nabywa dany towar, który u występujących w reklamie celebrytów powoduje nagły przypływ radości i wielką sławę, gdy okazuje się, że w jego przypadku była to tylko złudna obietnica szczęścia. Według Baumana: „Jednym z najistotniejszych skutków utożsamiania szczęścia z nabywaniem obdarzających szczęściem towarów

15 Z. Bauman, Konsumowanie życia, tłum. M. Wyrwas-Wiśniewska, Kraków 2009, s. 65.

16 Zob. Z. Bauman, Konsumowanie życia, dz. cyt., s. 66. 
jest nieustanne odkładanie nadziei na to, że pogoń za szczęściem kiedyś się skończy. Poszukiwanie szczęścia nie może mieć kresu, oznaczałby on bowiem kres samej idei szczęścia, w jej obecnej wykładni”"17. Konsument wierzy, że realizowanie swoich potrzeb doprowadzi go do szczęścia. Problem polega na tym, że potrzeby konsumenckie nie mają końca, a na horyzoncie pojawiają się coraz to nowsze pragnienia. Tym, co nakręca spiralę konsumpcjonizmu, jest potrzeba doznawania potrzeb lub jak chce Bauman: „niespożyte pożądanie spożycia” ${ }^{18}$. Wbrew pozorom potrzeby konsumenckie nie dają się zaspokoić na dłuższy czas. „W ortodoksyjnej psychologii definiowało się potrzebę jako stan napięcia, które spada i przemija po jej zaspokojeniu. «Potrzebą» wprowadzającą w ruch członków społeczeństwa konsumentów jest zaś, wprost przeciwnie, chęć podtrzymania napięcia, a nawet jego wzmożenia"19. Celem mediów, organizacji, przedsiębiorstw, a także i samych jednostek jest ciągłe kreowanie potrzeb oraz dążenie do ich zaspokojenia. W tej wizji owo dążenie jest kluczem. Dążenie nie gwarantuje jednak osiągnięcia spełnienia. Sygnalizuje ono jedynie możliwość realizacji potrzeb z nadzieją na doznanie szczęścia. W terminologii ponowoczesności i społeczeństwa konsumentów nacisk kładziony jest właśnie na dążenie. Gdyby każda jednostka nie kierowała się imperatywem ciągłego dążenia - społeczeństwo konsumentów doznałoby klęski. Poprzednie pokolenia odkładały zaspokojenie potrzeb na dalszy plan. Społeczeństwo ponowoczesne ma problem z osiągnięciem zaspokojenia potrzeb, gdyż popyt wciąż rośnie. Według Baumana w społeczeństwie ponowoczesnym nie chodzi już nawet o próbę zaspokajania potrzeb, ale o samo pożądanie: „Pożądanie jest z istoty swej narcystyczne: czyni siebie swym głównym obiektem i z tej racji pozostaje nienasycone, jak wielki stos innych (fizycznych lub psychicznych) obiektów nie znaczyłby jego drogi" ${ }^{20}$. Niezaspokojenie pożądania wynika stąd, że domaga się ono coraz to nowszych zachcianek.

17 Z. Bauman, Sztuka życia, dz. cyt., s. 22.

18 Z. Bauman, Konsumując życie, [w:] Konsumpcja - istotny wymiar globalizacji kulturowej, red. A. Jawłowska, M. Kempny, Warszawa 2005, s. 21.

19 Z. Bauman, Konsumując życie, dz. cyt., s. 20.

20 Z. Bauman, Konsumując życie, dz. cyt., s. 21. 
Niejeden stwierdzi, że takie postępowanie prowadzi do błędnego koła. Problem jednak polega na tym, że przeciętny członek społeczeństwa ponowoczesnego nie będzie zdawał sobie z tego sprawy. Jak pisze Bauman: „Racjonalność społeczeństwa konsumentów opiera się na irracjonalności składających się nań jednostek" ${ }^{21}$. Kupujący, konsumenci, członkowie społeczeństwa postrzegani są jako: „chorzy na umyśle, naiwne, oszukane ofiary zbiorowej hipnozy"22. Problem tylko w tym, że sami nie zdają sobie z tego sprawy ${ }^{23}$. Według Baumana: „Szczęście w postaci antycypowanego stanu błogości, mającego nastać po dokonaniu zakupu, zostaje niepostrzeżenie zastąpione przez poprzedzający ów stan akt nabywania, akt pełen radosnych oczekiwań, przesycony czystą i nieskazitelną, bo jeszcze niezawiedzioną, nadzieją"24.

\section{Media, reklama i wartość celebrytów}

Szczęście w rozumieniu konsumentów, członków społeczeństwa ponowoczesnego związane jest z propagandą i agitacją świata reklamy. Bauman opisuje zdarzenie mające uświadomić, jak wielką wagę we współczesnym świecie odgrywa marka. Przywołuje zachowanie kobiety, która przeglądając czasopisma, dowiaduje się, co powinno znaleźć się w jej szafie. Oglądając reklamy, zostaje utwierdzona w przekonaniu, że kupując dane spodnie, będzie czuła się ,jak nigdy”. Ponadto jej ulubione czasopismo sugeruje również gwarancję satysfakcji i poczucie bycia szczęśliwym. Kobieta kupuje więc owe spodnie. Jednak w domu szybko przekonuje się, że raczej nie wygląda w nich korzystnie - są za krótkie. Jej odczucie zmienia się, gdy pewnego dnia na okładce jednej z gazet widzi modelkę właśnie w tych spodniach. Uświadamia sobie wówczas, że żeby dobrze wyglądać, być dostrzegalną, czuć się tak piękną jak modelka, musi założyć

21 Z. Bauman, Konsumując życie, dz. cyt., s. 25.
22 Z. Bauman, Konsumując życie, dz. cyt., s. 25.
23 W swojej książce Gen X analizowała zachowania konsumenckie dawniej i w społeczeństwie XX w. Zob. B. Brzozowska, Gen X. Pokolenie konsumentów, Kraków 2005.

${ }_{24}$ Z. Bauman, Sztuka życia, dz. cyt., s. 23. 
te spodnie. W końcu tylko one powodują radość na twarzy modelki, a skoro ona jest radosna, to pewnie każda inna kobieta również będzie. Jak komentuje Bauman: „Oto, co mogą zrobić dla klientów marka, logo i umiejętna reklama: mogą się stać przewodnikami na krętej i najeżonej pułapkami drodze ku szczęściu. Szczęściu, które płynie z faktu uzyskania miarodajnego i uznanego powszechnie zaświadczenia, potwierdzającego (w sposób autorytatywny!), że podąża się właściwą ścieżką, że pozostaje się w grze i ma się prawo nie porzucać nadziei”25. W tym przypadku zaświadczenie potwierdzające osiągnięcie szczęścia zostało wydane właśnie przez modelkę pokazującą się w określonym stroju. To ona na ten krótki czas stała się synonimem szczęścia, tym samym dała nadzieję sporej liczbie osób na osiągnięcie szczęścia.

W kreowaniu poczucia szczęścia ważne są również głosy autorytetów, czyli celebrytów, marki. W świecie konsumpcji są to terminy równoznaczne. Zdobywają oni zaufanie konsumenta, przez co w jego przekonaniu niejako ponoszą odpowiedzialność za jego wybory. Jest to tylko złudne przekonanie, które w praktyce okazuje się fałszywe. Jednak każdy konsument potrzebuje stałego punktu odniesienia, by nie zgubić się w gąszczu sugestii. Celebryta $\mathrm{z}$ tego powodu, że jest powszechnie znany, staje się jakimś gwarantem i swego rodzaju zabezpieczeniem przed rozczarowaniem. Każdy go zna, istnieje realnie i jeszcze wypowiada się $\mathrm{z}$ aprobatą $\mathrm{w}$ różnych dziedzinach życia, sugeruje, nawołuje i reprezentuje swoją osobą określone wartości, które pociągają za sobą kolejne. Celebryci w idealny sposób wykorzystują zagubienie konsumenta spowodowane chociażby tym, że ma on problemy z określeniem własnej tożsamości. Według myślicieli analizujących ponowoczesność człowiekowi jedna tożsamość nie jest dana na całe życie. Podmiot może żonglować tożsamościami i dobierać je wedle uznania. Wartości tradycyjne i konserwatywne ujmowanie np. własnego pochodzenia schodzi na dalszy plan. Brak zakotwiczenia $\mathrm{z}$ jednej strony jest symbolem wolności, zaś z drugiej sprzyja poczuciu zagubienia. Wolność staje się tu wyzwaniem i imperatywem nakazującym odszukanie siebie i własnej tożsamości. 


\section{Szczęście jako wyzwanie}

Gdyby przełożyć myśl Tatarkiewicza na grunt ponowoczesności, można by powiedzieć, że nie ma po co i na co czekać. Przeciętny konsument, członek społeczeństwa ponowoczesnego nie może odkładać na później podsumowania swojego życia (tego, które dokonuje się na koniec ziemskiej wędrówki). Dzień w dzień odbywają się skrupulatne obliczenia i porównywania ze statystykami w pogoni za szczęściem. Ścigamy się w kwestii zarobków, wykształcenia, jakości ubrań, miejsca zamieszkania, wysokości kredytu, posiadanych dóbr. Wszystkie wymienione tu wartości zostają podświadomie sprowadzone do wartości wymiennych i materialnych. Tam, gdzie to możliwe, dominuje wartość pieniądza. Jest ona bezdyskusyjna, nie relatywna. Szczęście obecnie należy osiągać, tak jak osiąga się lepsze wyniki w sporcie, większe prędkości na torze jazdy, satysfakcję seksualną. To jest współczesne zadanie człowieka. Jak stwierdza Bauman: „Błogi stan szczęśliwości jest nie do osiągnięcia, jedynie pogoń za uparcie umykającym celem może dać goniącym choćby namiastkę szczęścia. Na bieżni wiodącej do szczęścia brak linii mety"26.

Wspólnym mianownikiem poczynań człowieka jest jego zdolność kredytowa, limit na karcie bankowej czy też po prostu posiadany zasób środków pieniężnych. Jak pisze Joanna Mysona Byrska: „Jeśli świat, tak jak przyjmuje Bauman, w społeczeństwie konsumpcyjnym odbywa się poprzez konsumpcję dóbr materialnych, to rola pieniądza, a dokładnie rzecz biorąc środków finansowych, jest o wiele większa niż w społeczeństwie produkcyjnym, które produkuje dobra w odpowiedzi na potrzeby jednostek. W społeczeństwie konsumpcyjnym wyprodukowane dobra oferowane są jednostkom, a jednostki dopiero muszą sobie uświadomić utajone do tej pory potrzeby konsumpcyjne i owe dobra nabyćn ${ }^{27}$. Według Byrskiej pod płaszczem konsumpcjonizmu kryje się przede wszystkim

26 Z. Bauman, Sztuka życia, dz. cyt., s. 22.

27 J. Mysona Byrska, Nowe wymagania wobec pracownika w kulturze nowego kapitalizmu, [w:] Fyzika a etika VII. Vesmir - priroda - clovek, red. I. Mihalikova, Nitra 2013, s. 81-88. 
kluczowa rola pieniądza jako środka do zaspokajania potrzeb, a także gwarancji poczucia stabilizacji. Nabywanie towarów i usług, do którego zredukowanie jest funkcjonowanie w społeczeństwie konsumpcyjnym, wpływa na wszystkie dziedziny życia człowieka. Kupowanie wyrobów z danego sklepu, korzystanie z usług konkretnej firmy, identyfikowanie się z odpowiednią marką pomagają człowiekowi w odnajdywaniu własnej tożsamości - zatem kształtują osobowość człowieka, wpływają na jego psychikę. Gdy korzysta on z artykułów danej firmy, jednocześnie identyfikuje się z jej polityką, która w przypadku każdego z koncernów może być kojarzona z innymi wartościami. Nie byłoby to możliwe, gdyby nie środek pośredniczący, jakim jest pieniądz. Odnajdywanie czy też budowanie własnej tożsamości jest dla jednostki zadaniem długotrwałym i wyczerpującym, jednak ma ono wpływ na poczucie szczęśliwości: „Brak szczęścia, niedobór szczęścia lub doznanie szczęścia nie tak intensywne jak to, które uznano oficjalnie za możliwe do osiągnięcia przez każdego, kto stara się jak należy i umiejętnie włada odpowiednimi narzędziami, są wystarczającym powodem, aby odrzucić posiadaną tożsamość i zabrać się do odkrywania czy wynajdywania innej"28.

Jeśli potraktujemy szczęście jako wyzwanie, to okaże się, że szanse jego zdobycia można nawet obliczyć. Jednak trudno stworzyć skalę porównywania wyników potencjalnych obliczeń. Pomimo to każdy członek społeczeństwa powinien zdawać sobie sprawę z odpowiedzialności, jaka na nim ciąży, odpowiedzialności za własne szczęście. W końcu, określając je i porównując do innych, bardzo łatwo o nieszczęście. Społeczeństwo konsumentów pełne jest namiastek szczęścia, przyjemności, pożądania - czegoś, co funkcjonuje jako szczęście, ale znacząco odbiega od tej definicji w myśl Tatarkiewicza. Również nauki starożytnych wydają się niedocenione, bo odstawione na półkę.

Słowem zakończenia można przytoczyć cytat z Epikteta, który również przywołuje Bauman w swoich rozważaniach. Może być on przestrogą, poradą, a przede wszystkim wskazówką dla tych, którzy jednak skierują się w stronę myśli starożytnych: „Pamiętaj, że w życiu winieneś 
się zachowywać jak na biesiadzie. Postawią przed tobą wokół krążąca misę - wyciągnij rękę i przyzwoicie weź swoją część. Idzie w ruch dalej - nie zatrzymuj! Nie doszła jeszcze do ciebie - nie wódź za nią z dala złaknionymi oczami, ale czekaj spokojnie, aż ta misa stanie przed tobą. Tak samo się zachowuj wobec dzieci, tak samo wobec żony, tak samo wobec godności, tak samo wobec bogactwa. [Nie trzeba pożądać, zazdrościć ani zagarniać. Gdy przyjdzie twoja kolej, otrzymasz należną ci porcję]" 29 .

Ponadczasową radą staje się umiar w dążeniach, cierpliwość, opanowanie - wartości inne niż te, które są wynoszone na piedestał w społeczeństwie ponowoczesnym. Mogą stać się one receptą na bolączki współczesnego człowieka, a także ukazać inny rodzaj szczęścia - płynący ze spełnienia życiowego i odwołujący się do teorii Tatarkiewicza i starożytnych.

\section{Bibliografia}

Aldrige A., Konsumpcja, tłum. M. Żakowski, Warszawa 2006.

Arystoteles, Etyka nikomachejska, tłum. D. Gromska, ks. I, http://sady.up.krakow.pl/antfil. arystoteles.etykanikom.htm (9.06.2015).

Bauman Z., Konsumowanie życia, tłum. M. Wyrwas-Wiśniewska, Kraków 2009.

Bauman Z., Konsumując życie, [w:] Konsumpcja - istotny wymiar globalizacji kulturowej, red. A. Jawłowska, M. Kempny, Warszawa 2005, s. 17-36.

Bauman Z., Płynne czasy, tłum. M. Żakowski, Warszawa 2007.

Bauman Z., Sztuka życia, tłum. T. Kunz, Kraków 2009.

Brzozowska B., Gen X. Pokolenie konsumentów, Kraków 2005.

Copleston F., Historia filozofii, t. 1, tłum. H. Bednarek, Warszawa 2004.

Mysona Byrska J., Nowe wymagania wobec pracownika w kulturze nowego kapitalizmu, [w:] Fyzika a etika VII. Vesmir - priroda - clovek, red. I. Mihalikova, Nitra 2013, s. 81-88.

Platon, Protagoras, http://katedra.uksw.edu.pl/biblioteka/platon_protagoras.pdf(9.06.2015). 
Seneka, Myśli, tłum. S. Stabryła, Kraków 1989.

Tatarkiewicz W., O szczęściu, Warszawa 1979.

Tomasz z Akwinu św., O szczęściu, [w:] Cel ostateczny czyli szczeście, tłum. F. W. Bednarski, zag. 5, http://www.katedra.uksw.edu.pl/suma/suma_indeks.htm (9.06.2015). 